\title{
THE IMPACT OF COVID-19 ON HOTEL INDUSTRY IN ASIAN COUNTRIES
}

\author{
Indriyani Tri Agustina ${ }^{1}$, Rolisda Yosintha ${ }^{2}$ \\ ${ }^{1,2}$ Faculty of Teacher Training and Education Tidar University \\ J1. Kapten Suparman No.39, Tuguran, Potrobangsan, Kec. Magelang Utara, Kota \\ Magelang, Jawa Tengah 56116 \\ indryaniagustin02@gmail.com, rolisda@untidar.ac.id
}

Received: 15 Juni 2020. Approved: 22 Nopember 2020. Published: 30 Desember 2020

\begin{abstract}
The spread of Covid-19 has led to a global problem in all aspects of life, including in the tourism sector that directly affects the hotel industry. Asia as a continent with many countries that rely most of their revenue on tourism suffers a severe blow. The purpose of this study was to investigate the impacts of the novel Covid-19 on the hotel industry in Asian countries. Through a descriptive qualitative method, the researchers collected data from journals, research reports, books, government documents, articles, and websites. In analyzing the data, the researchers make a comparison between the Asian continent and other continents such as Europe, America, Africa, and Australia by focusing on the hotel occupancy in those continents. The result shows that the rate of hotel occupancy in Asia dropped by $57 \%$ and 63,4 million employees lose their jobs. This condition is mainly caused by the travel ban regulation that is followed by the temporary closure of tourist destinations. The hotel industry in Asia has lost up to US\$ 1.041 million due to massive booking cancellations, and employees in this industry are even more severely affected as they have no income to support their life.
\end{abstract}

Keywords: Asia, Covid-19, hotel industry

(C) 2020 Direktorat Kajian Strategis

\section{INTRODUCTION}

Covid-19 is an infectious deadly disease that is caused by a new type of coronavirus that is never known before. This virus was first detected in Wuhan, China, in December 2019. Covid-19 is not a disease that can be underestimated as the spread of the virus is very fast and aggressive. According to Worldometers (2020), the total case of Covid-19 across the world are 5.339.096 cases with 340.696 deaths on May 23, 2020. This virus can be transmitted through close contact with an infected person. When an infected person sneezes or coughs, the droplet may contain viruses that may enter the body of the nearby individual so that she or he will be infected as well. The infected person will show symptoms like cough, fever, sore throat, chills, muscle pain, and difficulty in breathing.

Indeed, Covid-19 is even more dangerous because there are people who do not show the symptoms but can still transmit the virus to other people; they are called the silent spreaders. These people carry the virus with them without 
showing any signs of illness, fever, or cough. There are three types of silent spreaders, namely asymptomatic, presymptomatic, and very mildly symptomatic. Asymptomatic carriers are people who carry an active virus in their body, but they have never experienced any symptoms such as fever, coughing, breathing issues, or gastrointestinal issues. It is difficult to identify when someone has the disease but do not show any symptoms of it. Pre-symptomatic carriers are people who have been infected and are isolating themselves, but they have not shown any symptoms. People who are in the pre-symptomatic phase usually can transmit the virus in one to three days before they begin to show the symptoms. The last, very mildly symptomatic carriers are those who feel a little sick but still do an activity in close contact with others. The symptoms begin with mild fever or slight cough, but they always go to public places and indirectly spread the virus. After all, even though the symptoms shown are in a light category, the virus can still be transmittable and endangers other people.

In addition to the fatal implications for people's health, Covid19 has affected many aspects of life all around the world, such as in the economy, transportation, tourism, etc. On the economic side, the spread of coronavirus has negatively affected the economy of many countries all over the globe, particularly that of developing countries such as Asian countries. This virus has slowed down the growth of the economy in many ways. For example, the slowing trade between Indonesia and China due to the massive ban on travel and the shutdown of transportation access has disrupted the distribution, production, and consumption activities. Indeed, China is the center of the economy and the main player of export and import in Asia. Due to the fast spread of Covid-19, the demand for exports and imports to China has declined significantly, and thus damaging their economy. When China's economy is in trouble, it is most likely that the other countries that have a business relation with China will get impacted too. The effects of Covid-19 on the economy are even more severe for small businesses. Pressure due to being unable to carry out business activities and the deterioration of economic activity make them decide to close their business, and thus causing many people to lose their jobs.

Other than effects on the global economy, Covid-19 also shuts down public transport since the use of public transport may increase the spread of the virus. To prevent this massive transmission, many countries have enacted rules on the travel ban. For example, the Indonesian government has implemented a large-scale social restriction (PSBB) since March 2020. Residents are not allowed to leave their houses for any unnecessary intentions. They cannot travel leaving their district, regency, or province. Bus stations, train stations, airports, and ports are all on shutdown, making it difficult for anyone to travel from one place to another, and thus reducing the spread of the virus. Similarly, the Philippines government has imposed travel restrictions since March 17, 2020. All of the transportation means in the Philippines, both private and public transport, are suspended during the lockdown to minimize the transmission of Covid-19 (Bisnis, 2020). It also happens in Thailand that all flights for exit and entry into Thailand are suspended. This regulation is strictly implemented by Thai people to push the number of coronavirus cases, resulting in no new cases on May 22, 2020 (WHO, 2020).

The global shutdown, in a more knock-on effect, has disturbed the tourism aspect as well. Limited mobility 
has decreased or even shut down many tourist destinations across the globe. The shutdown of tourism destinations is done to prevent the spread of the virus and decrease the death caused by Covid- 19 . A lot of tourism destinations in Asia are closed for both domestic and international travelers. The government around the world prioritizes the health and safety of their citizens and thus deciding to ban travel. For example, in Thailand, Legend Siam's amusement park has announced its closure starting March 3, 2020 due to a decline in visitors. In Hong Kong, Disneyland is also closed without any information as to when it will be on business again. In Indonesia, according to The District Government, some tourism destinations such as Tanah Lot, Ulun, Beratan, Jatiluwih, Bali Zoo, and GWK are temporarily closed on March 22-30, 2020. In Japan, some tourism places such as Tokyo Disneyland, Cup Noodles Museum, Engakuhi Temple, and others are closed temporarily (Japan-guide, 2020). In South Korea, the entrance to Seokchon Lake is also temporarily closed until midApril to prevent people from visiting this tourist attraction during the coronavirus pandemic (koreatravelpost, 2020). Besides, public places that have the potential to cause crowds such as restaurants, places of worship, and malls are also temporarily closed (KOMPAS, 2020).

Tourism is a vital source of a country's national revenue. In some countries in Asia, tourism provides most of the government's revenue. One of the Asian countries that earn high revenue from tourism is Thailand. According to Knoema (2018), in 2018, tourism in Thailand, Indonesia, Srilanka, and Japan contributed $21.6 \%, 6 \%, 12.5 \%$, and $7.4 \%$ to its Gross Domestic Product (GDP) respectively. Vietnam also benefitted from the tourism sector as much as $15.4 \%$ contribution to its GDP as this country welcomed 16.3 million international travelers in 2019 (Vietnam Briefing News, 2019). Indeed, the loss caused by the massive impact of Covid19 on the tourism sector has led to deeper detrimental consequences on many tourism sub-sectors, including the hospitality industry, particularly the hotel industry in Asian countries.

According to Travel Agent Central (2017), Asia is the second most visited continent in 2016 with $19.5 \%$ visits, following Europe in the first place with $58 \%$ visits. For developing countries like many countries in Asia, tourism plays a highly important role in three aspects, namely income generator, employment, and foreign-exchange earnings. The hotel industry in China contributed to the nation's GDP by $11 \%$ in 2017 (China tourism and hotel industry, 2018). Vietnam, one of the most attractive countries in ASEAN, was supported by its hotel industry at around $€ 208.1$ billion with an annual growth rate of $6.7 \%$. The country's nominal Gross Domestic Product (GDP) is estimated at $€ 248.8$ billion in 2020 (UK-ASEAN business council, 2018). Meanwhile, the hotel industry in Lebanon gave \$203 in July 2018 (Vilis, 2019). In Indonesia, the hotel industry was able to pocket an income of around $\mathrm{Rp} 6.73$ trillion since September 30, 2019 (Investor daily Indonesia, 2020). However, since the outbreak of Covid-19, activities in the hotel industry in many Asian countries have stopped because a lot of tourists cannot travel anywhere. The hotel industry is seen to be facing new threats that have never been discovered before. Indeed, even though the hotel industry sector plays an important role in supporting national revenues, there is no deep research about that. Therefore, the researchers try to investigate the impacts of the novel Covid-19 on the hotel industry in Asian countries. 


\section{METHODOLOGY}

The objective of this study was to investigate the impacts of Covid-19 on the hotel industry in Asian countries. This study was conducted using a qualitative descriptive method. The purpose of a qualitative descriptive study is to investigate the quality of relationships, situations, activities, or materials (Fraenkell, 2012). The data were collected through library research. The sources of information were obtained from journals, websites, articles, government documents, research reports, and other information from various media both electronic and print. The data were collected by analyzing literature, websites, government documents, research reports, and journals. In analyzing the data, the researchers make a comparison between the Asian continent and other continents such as Europe, America, Africa, and Australia by focusing on the hotel occupancy in those continents.

\section{FINDINGS AND DISCUSSION}

The Asian continent consists of several regions such as East Asia, South Asia, West Asia, Southeast Asia, and Central Asia. In the hotel industry, Asia has a huge role in the growth of the country. Unfortunately, the spread of Covid-19 across the globe makes hotel industries in Asian countries deeply shaken. This condition has directly affected hotel occupancy rates in Asia because a lot of countries around the world have implemented a travel ban, physical distancing, and quarantine to stop the spread of the deadly virus.

In East Asia, especially in China, the rate of hotel occupancy has declined by $75 \%$ from 14 January 2020 (Hotel News Now, 2020). It is because a lot of domestic and international airlines cancel their flights to China and make the hotel room occupancy affected (Hoque, Shikha, Hasanat, Arif, \& Hamid, 2020). In Japan, hotel occupancy shows a considerable decline of $82.4 \%$ (Business Times, 2020). Meanwhile, in South Korea, the number of hotel occupancy experiences the worst and even drops to a single digit (Pulsenews, 2020).

In South Asia, such as in Srilanka, the hotel occupancy is below $10 \%$. It happens because a lot of visitors cancel and refund their booking as caused by the spread of Covid-19 (Nikkei Asian Review, 2020). In Bangladesh, the hotel occupancy hits around 30 to $40 \%$ decrease because of the cancelation of arrival visa (The Daily Star, 2020). Similarly, hotel occupancy in India has decreased by $43 \%$ (Str, 2020).

In Southeast Asia, the Indonesian Hotel and Restaurant Association (PHRI) said that since the outbreak of Covid-19 in January, hotel occupancy rates in Indonesia had fallen from 30 to $40 \%$ with Bali, Manado, Jakarta, Sulawesi, and Riau Islands as the worst-hit areas (The Jakarta Post, 2020a). In Singapore, the occupancy of hotels decreases by above $50 \%$ in March because of a lot of guests facing some issues like flight cancellation and quarantine (ETHospitalityWorld, 2020). Next in Vietnam, the Vietnam tourism advisory council claims that the hotel's occupancy from south to the north was dropped between 20 and $50 \%$ if compared from the last year. The number of domestic tourists in 2020 was reduced by $80 \%$ and the international visitors decreased by $60 \%$ due to the fears of the Covid-19, and this condition makes Vietnam's tourism in the next three months lose the income between $\$ 5.9$ to $\$ 7$ billion (Nguyen, 2020). Similarly, in Malaysia, the hotel occupancy decreases by $69.4 \%$ since March because of the booking cancelations (HVS, 2020). 
In West Asia, such as in Lebanon, the occupancy in the hotel stands at 5\%. To decrease the expenses, around $90 \%$ of hotels in Lebanon have stopped operation and closed down (Hotel Management, 2020). In Turkey, the number of hotel occupancy dropped by more than $50 \%$ (TRTWorld, 2020). It is because a lot of airlines have suspended the flights since travel restrictions and make the hotel rooms empty. Then, in Saudi Arabia, the hotel occupancy dropped by $22 \%$. This is the lowest performance in April this year and this pandemic makes the industry in
Saudi Arabia paralyzed (Hotelier ME, 2020).

Furthermore, in Central Asia for example Uzbekistan, the rate of hotel occupancy was below 25\% (Eurasia net, 2020). Meanwhile, for the other countries in Central Asia, such as Kazakhstan, Turkmenistan, Tajikistan, and Kyrgyzstan, there are no confirmed cases of Covid-19 because since the first of the spread corona virus the entry and the exit access in those regions were closed (Kalpak Travel, 2020).

In summary, the hotel occupancy in Asia as represented by some countries in all parts of Asia shown as follows:

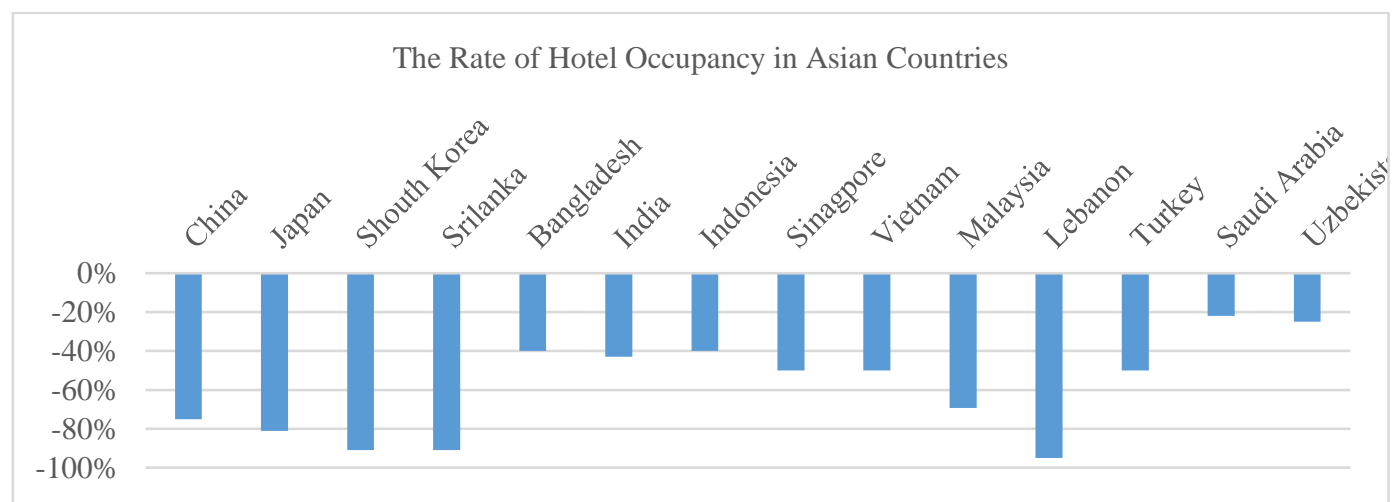

Figure 1. The Rate of Hotel Occupancy in Asian Countries

As seen in Figure 1, Covid-19 has significantly affected the hotel industry in most countries in Asia. The hotel occupancy is seen to be impacted due to the travel ban, visitors who cancel and refund the booking hotel, quarantine regulations, and so on. Generally, the average decline of hotel occupancy in Asian countries amounted to $58.74 \%$. Because of the decline of hotel occupancy, it also impacted employment in the hotel industry. For example, in Indonesia, more than 150,000 employees have been laid off (The Jakarta Post, 2020b). Then, since March 4, 2020 in Malaysia, around $4 \%$ of hotel industry workers have been laid off with pay cuts and unpaid leave. Hotels in India implement a pay cut off up to 40 to 60 percent for the managers and the founders and apply a paid voluntary resignation for 400 employees (str, 2020a). In Vietnam, around 23,000 workers have been forced to take temporary leave (ILO, 2020). Then, in Lebanon, there is a hotel that shut down the hotel because it cannot pay the tax and make their employees lose their jobs. The total job losses in Asia have reached 63.4 million. Besides, the Gross Domestic Product (GDP) in Asian countries also get the impact. Because most of their income comes from tourism, they suffer a loss of around US\$ 
1.041 million (World Travel \& Tourism Council, 2020).

Indeed, the decline in hotel occupancy does not only happen in Asian countries. It also happens in most continents such as in Europe, Africa, America, and Australia. In Europe, this declining trend in hotel occupancy has started since the first cases of Covid-19 was confirmed in France on January 24, 2020. This deadly virus has a devastating effect on the hotel industry across Europe especially in Italy where the number of cases escalates quickly and drops hotel occupancy by $85 \%$ (Hospitality Net, 2020). Similarly, Swiss and France experience the same decline by $52.4 \%$ and $35.7 \%$ respectively (Hospitality Net, 2020) with job losses of 13.0 million.

Like the other continents, Africa also gets the impact of Covid-19 in the hotel industry. On March 16, 2020, the hotel occupancy in some regions such as Mauritius, Nairobi, and Marrakech dropped by $70 \%, 80 \%$, and $73 \%$ respectively (str, 2020b). In general, the rate of hotel occupancy in Africa is now below $30 \%$. It happens because there is a lockdown regulation that makes the hotel occupancy get the heavy blows. It disadvantaged those countries for before the Covid-19, the hotel industry contributed 8\% to the economy in Africa (Statista, 2020).

Moreover, in the United States, the level of hotel occupancy is slightly above $40 \%$. For example, in New York, the number of hotel occupancy is only $47.6 \%$, Georgia 40.7\%, and Florida $44.0 \%$ (str, 2020c). Next, in Australia, especially in Darwin and Sydney, the hotel occupancy dropped by $15 \%$ in February (The Sydney Morning Herald, 2020), and for Queensland in April, the occupancy on hotels decreased by $13.8 \%$ (Tourism and Events Queensland, 2020). Therefore, the average level of hotel occupancy in Australia as the impact of Covid-19 is below $15 \%$.
As shown in the data, almost all countries in all continents experience a dramatic decline in their hotel occupancy. In Asian countries, the average decline in hotel occupancy is $58.74 \%$. In Europe, the decline of hotel occupancy is slightly lower than in Asia with $57.70 \%$. Africa, America, and Australia are in a better condition with less than $50 \%$ decline in hotel occupancy, i.e. $25.6 \%, 44 \%$, and $14.60 \%$ respectively. Therefore, it is clear that Asian countries get the most severe effect of Covid-19 on their hotel industry. This condition is partly caused by the fact that most Asian countries rely on tourism a lot. When there is no tourist due to the global travel ban, no hotels will have guests to fill their rooms. Consequently, a lot of their employees must experience lay off or salary reductions.

\section{CONCLUSION}

The findings of this study show that the spread of Covid-19 has greatly affected the hotel industry all around the world, not only in Asia but also in the other continents such as Europe, Africa, America, and Australia. However, the continent that gets the most significant impact is Asia. Most Asian countries are depending on their tourism industry, which directly affects their hotel industry. With an average of $57.70 \%$ of decline in hotel occupancy, as many as 63.4 million employees in this industry are losing their income, leading to a more knock-on effect on employability. To minimize the negative impacts, some measures be implemented. Giving promotion packages with adorable prices can attract visitors to stay in the hotel. Promoting Flexi-rate can also increase hotel occupancy for visitors can flexibly change the date of booking to the other day if there is an unpredictable moment like this pandemic. More importantly, increasing hotel service in terms of 
cleanliness must be carried out to guarantee guests' health and safety during their stay. Furthermore, for the government, it is better to reduce the tax because since the Covid-19, the income that hotels earn does not match their daily operating expenses, and thus reducing tax could help hotels to revive.

\section{REFERENCES}

Bisnis. (2020, March 19). Noudettu osoitteesta Bisnis.com: https://ekonomi.bisnis.com/read/2020 0319/98/1215659/cegah-corona-inikebijakan-transportasi-umum-dinegara-lain

Business Times. (2020, April 13). Noudettu osoitteesta The Business Times: https://www.businesstimes.com.sg/re al-estate/march-hotel-occupancy-ratein-japan-lowest-on-record-survey

Center for disease control and prevention. (2020, May 12). Noudettu osoitteesta Centers for Disease Control and Prevention. Retrieved from https://www.cdc.gov/coronavirus/201 9 ncov/hcp/faq.html

China Tourism and Hotel Industry Analysis, Trends, Growth. (2018). Noudettu osoitteesta https://www.mordorintelligence.com/ industry-reports/china-tourism-andhotel-industry.

ETHospitalityWorld. (2020, April 21). Noudettu osoitteesta ETHospitalityWorld.com: https://hospitality.economictimes.indi atimes.com/news/hotels/covid-19impacts-hotel-occupancy-in-theasean-region $/ 75267521$

Eurasianet. (2020, June 3). Noudettu osoitteesta https://eurasianet.org/: https://eurasianet.org/uzbekistan-toptier-hotels-linger-on-market

Fraenkell, J. R. (2012). How to Design and Evaluate Research in Education (Eight Ed). 426.

Hoque , A.;Shikha, F. A.;Hasanat , M. W.; Arif , I.;\& Hamid, A. A. (2020). The Effect of Coronavirus (COVID-19) in the Tourism Industry in China. Asian
Journal of Multidisciplinary Studies, 3(1), 52-58.

Hospitality Net. (2020, March 25). Noudettu osoitteesta

https://www.hospitalitynet.org/:

https://www.hospitalitynet.org/opinio n/4097757.html

Hotel management. (2020, March 23). Noudettu osoitteesta https://www.hotelmanagementnetwork.com/: https://www.hotelmanagementnetwork.com/news/hotels-lebanonjobs-coronavirus/

Hotel News Now . (2020, February 4). Noudettu osoitteesta http://hotelnewsnow.com/: http://hotelnewsnow.com/Articles/30 0124/Coronavirus-Preliminary-hotelperformance-impact

HotelierME. (2020, May 12). Noudettu osoitteesta HotelierME: https://www.hoteliermiddleeast.com/ business/117482-report-jeddah-hoteloccupancy-levels-falls-to-22

Huang, P. (2020, April 13). Noudettu osoitteesta

https://www.npr.org/sections/goatsan dsoda/2020/04/13/831883560/can-acoronavirus-patient-who-isntshowing-symptoms-infect-others

HVS. (2020, May 5). Noudettu osoitteesta https://www.hvs.com/: https://www.hvs.com/article/8768hvs-covid-19-impact-on-hotels-inasia-pacific

ILO. (2020, April 24). Noudettu osoitteesta ilo.org/covid19:

https://www.ilo.org/wcmsp5/groups/p ublic/---asia/---ro-

bangkok/documents/briefingnote/wc ms_742664.pdf

Investor daily Indonesia. (2020, January 15). Noudettu osoitteesta https://investor.id/business/omzetbisnis-hotel-tembus-rp-673-triliun: https://investor.id/business/omzetbisnis-hotel-tembus-rp-673-triliun

Japan-guide. (2020, May 26). Noudettu osoitteesta https://www.japanguide.com: https://www.japanguide.com/news/alerts.html

Kalpak Travel. (2020, June 1). Noudettu osoitteesta Kalpak Travel: 
https://kalpak-

travel.com/blog/coronavirus-centralasia/

Knoema. (2018). Noudettu osoitteesta Knoema:

https://knoema.com/atlas/Indonesia/t opics/Tourism/Travel-and-Tourism-

Total-Contribution-to-

GDP/Contribution-of-travel-andtourism-to-GDP

KOMPAS. (2020, March 23). Noudettu osoitteesta KOMPAS.com: https://travel.kompas.com/read/2020/ 03/23/182800127/tempat-wisata-dibali-tutup-sementara-guna-antisipasivirus-corona?page $=$ all

koreatravelpost. (2020, March 30). Noudettu osoitteesta

https://www.koreatravelpost.com: https://www.koreatravelpost.com/cor onavirus-impact-on-korean-tourismindustry/

Nguyen, T. (2020, March 17). Noudettu osoitteesta - The Diplomat: https://thediplomat.com/2020/03/viet nams-coronavirus-strugglemanaging-the-economic-impact/

Nikei Asian review. (2020, April 3). Noudettu https://asia.nikkei.com/: https://asia.nikkei.com/Spotlight/Cor onavirus/Empty-hotels-in-Sri-Lankaand-Nepal-point-to-lengthyeconomic-hit

pulsenews. (2020, March 6). Noudettu osoitteesta https://pulsenews.co.kr/: https://pulsenews.co.kr/view.php?yea $\mathrm{r}=2020 \& \mathrm{no}=237896$

Statista. (2020, May 12). Noudettu osoitteesta https://www.statista.com/: https://www.statista.com/statistics/11 04835/coronavirus-travel-tourismemployment-loss/

str. (2020a, April 1). Noudettu osoitteesta str: https://str.com/data-insightsblog/covid-19-india-hotelperformance-impact

str. (2020b, March 27). Noudettu osoitteesta https://str.com/: https://str.com/datainsights-blog/covid-19-impact-africahotel-performance

str. (2020c, June 3). Noudettu osoitteesta str: https://str.com/press-release/str-ushotel-results-week-ending-30-may
The Jakarta Post. (2020a, April 2). Noudettu osoitteesta

https://www.thejakartapost.com/: https://www.thejakartapost.com/trave 1/2020/04/02/covid-19-almost-700hotels-in-indonesia-shut-down.html

The Jakarta Post. (2020b, April 7). Noudettu osoitteesta

https://www.thejakartapost.com/: https://www.thejakartapost.com/trave 1/2020/04/07/covid-19-at-least-1266hotels-in-indonesia-have-closed.html

The Sydney Morning Herald. (2020, February 14). Noudettu osoitteesta The Sydney Morning Herald: https://www.smh.com.au/business/co mpanies/australian-hotels-catchcoronavirus-cold-as-visitorsplummet-20200212-p54017.html

Tourism and Events Queensland. (2020, February 3). Noudettu osoitteesta https://teq.queensland.com/:

https://teq.queensland.com/researchand-insights/economics-andspecialised-reports/accommodation

Travel Agent Central. (2017, March 31). Stats: Europe Was Most-Visited Continent In 2016. Noudettu osoitteesta https://www.travelagentcentral.com/: https://www.travelagentcentral.com/r unning-your-business/stats-europewas-most-visited-continent-2016

TRTWorld. (2020, May 6). Noudettu osoitteesta How Turkey and Europe plan to reopen for tourism: https://www.trtworld.com/magazine/ how-turkey-and-europe-plan-toreopen-for-tourism-36073

UK-ASEAN business council. (2018). Vietnam Hospitality Report 2018. Vietnam: EU-Vietnam Business Network (EVBN).

Vietnam Briefing News. (2019, December 13). Noudettu osoitteesta Vietnam Briefing News. Accessed from https://www.vietnambriefing.com/news/vietnams-tourismsector-opportunities-investors2020.html/

Vilis, S. H. (2019, September 13). Noudettu osoitteesta https://blog.blominvestbank.com/311 38/beiruts-hotel-occupancy-rate-at- 
70-20-by-july-2019/:

https://blog.blominvestbank.com/311 38/beiruts-hotel-occupancy-rate-at-

70-20-by-july-2019/

WHO. (2020, May 22). Coronavirus disease 2019 (COVID-19) WHO Thailand Situation Report - 22 May 2020. Noudettu osoitteesta https://reliefweb.int/report/thailand/c oronavirus-disease-2019-covid-19who-thailand-situation-report-22osoitteesta may-2020

https://www.worldometers.info/coron avirus/
World Travel \& Tourism Council. (2020, May 12). Noudettu osoitteesta https://wttc.org/: https://wttc.org/News-Article/WTTCnow-estimates-over-100-millionjobs-losses-in-the-Travel- \&-Tourismsector-and-alerts-G20-countries-tothe-scale-of-the-crisis

Worldometers. (2020, May 23). Covid-19 coronavirus pandemic. Noudettu 